\title{
Maquiavelismos e governos na América portuguesa: dois estudos de ideias e práticas políticas
}

\author{
Rodrigo Bentes Monteiro[1], Vinícius Dantas[2]
}

\section{Resumo}

Este artigo versa sobre dois estudos de práticas e ideias políticas pertinentes ao contexto da América portuguesa e suas possíveis relações com o opúsculo O príncipe, de Nicolau Maquiavel. No governo-geral do conde de Óbidos (1663-1667), verificam-se algumas semelhanças com os conselhos escritos pelo secretário florentino. Por sua vez, em meio ao governo do conhecido conde de Assumar na capitania de São Paulo e Minas do Ouro (1717-1721), produziu-se um documento cujas ideias de poder são fortemente associadas à cultura clássica. Nem por isso, seu coautor fazia-se distante do repudiado autor renascentista. Os dois casos supõem a pertinência de se analisarem as ideias de Maquiavel no âmbito da monarquia portuguesa e de sua cultura letrada, seja pela aproximação entre modos de governar, seja por uma estratégia que visava, provavelmente, dissimular a sua inspiração.

Palavras-chave: maquiavelismo; América portuguesa; práticas e ideias políticas.

\section{Maquiavelismos y los gobiernos en la América portuguesa: dos estudios de las ideas y prácticas políticas}

\section{Resumen}

En este trabajo se analizan dos estudios sobre las prácticas y las ideas políticas relevantes para el contexto de la América portuguesa y sus posibles relaciones con el folleto El príncipe, de Nicolás Maquiavelo. En el gobierno general del conde de Óbidos (1663-1667), hay algunas similitudes con las recomendaciones escritas por el secretario florentino. Mientras tanto, en el gobierno del notorio conde de Assumar en la capitanía de São Paulo y Minas do Ouro (1717-1721), se elaboró un documento con ideas de poder fuertemente asociadas con la cultura clásica. Pero no por ello su coautor se apartaba del repudiado escritor renacentista. Los dos casos suponen la relevancia de examinar las ideas de Maquiavelo bajo la monarquía portuguesa y su cultura literaria, sea por el acercamiento entre los modos de gobernar, o por una estrategia destinada a ocultar, probablemente, su inspiración.

Palabras clave: maquiavelismo; América portuguesa; prácticas y ideas políticas.

\section{Machiavellianisms and governments in Portuguese America: two analyses of ideas and political practices}

\section{Abstract}

This article describes two studies regarding political practices and ideas that are relevant to the context of Portuguese America and its possible relations with the opuscule The prince, by Niccolò Machiavelli. In the general government of the Count of Óbidos (16631667), some similarities with the advisement written by the Florentine secretary can be observed. However, during the administration of the famous Count of Assumar, in the captaincy of São Paulo and Minas do Ouro (1717-1721), a document was produced, and its ideas of power are strongly associated with the classic culture. However, this was not a reason for its coauthor to be distant from the condemned renaissance author. Both cases indicate the pertinence of analyzing the ideas by Machiavelli in the scope of Portuguese monarchy and its literate culture, be it by the approximation between types of government or be it because of a strategy that probably aimed at dissimulating its inspiration.

Keywords: Machiavellianism; Portuguese America; political practices and ideas.

Machiavélisme et les gouvernements dans l'Amérique portugaise: deux études d'idées et de pratiques politiques Résumé

Dans ce travail, deux études sur pratiques et idées politiques seront analysées dans le contexte de l'Amérique portugaise et ses possibles relations avec l'opuscule de Nicolo Machiavelli, Le prince. Dans le Gouvernement Général du conde de Obidos (1663-1667), on voit certaines similitudes avec les conseils écrits par le Florentin secrétaire. À l'époque du gouvernement du conde de Assumar à la capitainerie de São Paulo et Minas do Ouro (1717-1721), un document de discussion a été produit, dont les idées étaient fortement corrélées à la culture classique. Pour autant, le coauteur se faisait lointain du repudie auteur de la Renaissance. Les deux cas supposent la pertinence de analyser les idées de Machiavel dans le contexte de la monarchie portugaise et sa culture, soit au niveau de la similitudes des modes de gouverner, soit au niveau de une stratégie visant à dissimuler sa inspiration.

Mots clés: machiavélisme; l'Amérique portugaise; pratiques et idées politiques.

Artigo recebido em 18 de Abril de 2014 e aprovado para publicação em 06 de Junho de 2014.

[1] Departamento de História da Universidade Federal Fluminense (UFF) - Niterói (RJ) - Brasil. E-mail: rodbentes@historia.uff.br

[2] Departamento de História da Faculdade de Filosofia e Ciências Humanas da Universidade Nova de Lisboa - Lisboa - Portugal.

E-mail: viniciusdantas2000@yahoo.com.br 
U ma carta escrita em Paris por D. Vasco Luís da Gama, marquês de Niza e embaixador de D. João IV, ao seu amigo em Roma D. Vicente Nogueira, expressa o interesse de nobres portugueses por Maquiavel no século XVII. Nela, o marquês lembrou que, em Lisboa, muitos fidalgos liam o referido autor "sem licença nem escrúpulo". ${ }^{1}$ A denúncia fazia sentido, pois cerca de dois anos antes o bispo e inquisidor-geral de Portugal, D. Francisco de Castro, anulou todas as licenças eclesiásticas para leitura e posse de "livros de hereges, suspeitos na fé, ou condenados por alguns outros legítimos respeitos". Até a primeira metade do Setecentos, mesmo religiosos com autorização para ler livros proibidos pela Inquisição não podiam portar obras de Maquiavel. Os escritos do autor florentino deviam ser guardados "em segredo e fechados à chave para não passarem às mãos de outrem".3

Era arriscado defender publicamente as ideias de Maquiavel no mundo português. Com a vigilância inquisitorial, os admiradores do secretário florentino expressavam mais seu entusiasmo no âmbito privado. E os que falaram abertamente sobre Maquiavel em Portugal dos séculos XVII e XVIII fizeram-o em tom crítico, para demonstrar o perigo de suas ideias "contaminarem" o comportamento de soberanos e homens em geral. Acusava-se o autor de colocar os interesses dos príncipes acima da religião e dos súditos. Assim, os defensores de uma política baseada na moral cristã não esconderam sua oposição. Na segunda metade do Seiscentos, quando o fidalgo da Corte de D. João IV, Luís Abreu de Melo, criticou os príncipes que privilegiavam seus interesses em detrimento do bem comum dos vassalos, definiu esse "erro" como "maquiavelista, indigno de católico procedimento". ${ }^{4}$ No século seguinte, o padre Rafael Bluteau associou a palavra "maquiavelista" aos seguidores dos ensinamentos de Maquiavel, autor de livros políticos difusores de dogmas "perniciosos". Essas opiniões forjaram o "maquiavelismo", vocábulo que denunciava o uso de práticas políticas maliciosas pelos governantes para permanecerem no poder. O termo foi incorporado ao cotidiano para descrever alguém manipulador, cínico e perverso, agindo em todas as ocasiões para seus proveito e utilidade próprios.

Todavia, ao situarmos a obra de Maquiavel em seu contexto, aproximando-a de outros autores e escritos sobre a "arte do Estado", entendemos o maquiavelismo de forma mais ampla, vinculado a um modo de governar mais pragmático e/ou violento que, em meio à expansão ultramarina portuguesa na época moderna, não poderia ser explicitamente associado por seus protagonistas governantes aos conselhos do florentino. Por outro lado, esse tipo de governo tido como inescrupuloso e pouco cristão era combatido pelos ditames da

'Carta, 27/09/1647, Biblioteca Nacional de Portugal (BNP), cód. 2667, fl. 159-160v.; João Carlos Gonçalves Serafim; José Adriano de Freitas Carvalho (orgs.), Um diálogo epistolar. D. Vicente Nogueira e o marquês de Niza (1615-1654), Porto, Afrontamento, 2011, p. 121.

2Provisão, 30/08/1645, Arquivo Nacional da Torre do Tombo (ANTT), Tribunal do Santo Ofício, Conselho Geral, livro 213, fl. 453-457.

33úplica, 11/11/1704, Biblioteca da Ajuda (BA), cód. 54-IX-31, nº 28; Despacho, 11/02/1705, BA. cód. 54-IX-31, n. 28. ${ }^{4}$ Luis Abreu Mello, Avizos pera o paço offerecidos a Rodrigo de Salazar, \& Moscoso, Lisboa, Officina Craesbeckiana, 1659, p. 70.

${ }^{5}$ Rafael Bluteau, "Machiabelista”, In: Vocabulário portuguez \& latino, vol. 5, Lisboa, Oficina de Pascoal da Silva, 1716, p. 234 
Inquisição e da Reforma católica, sendo formalmente rechaçado como maquiavelista. Trata-se, assim, de um ambiente apenas aparentemente hostil às ideias de Maquiavel, cuja influência não raro era disfarçada por trás de referências e leituras mais aceitas. Desse modo, é possível situar o autor proibido no debate sobre a legitimidade dos interesses de príncipes no governo, mais difundido após a recepção da obra de Cornélio Tácito e as discussões sobre as razões de Estado na segunda metade do século XVI. Em suas viagens pelas cortes europeias no mesmo período, Giovanni Botero ouvia a nobreza discutindo sobre a "Razão de Estado e a citar ora Maquiavel, ora Tácito".

Essa interpretação também permite associar teorias sobre a conservação do poder dos príncipes a estudos de casos, compreendendo a atuação de certos governantes da época moderna no debate. Na América portuguesa dos séculos XVII e XVIII, seria possível um governador se inspirar nos ensinamentos de Maquiavel e demais autores que refletiram sobre a "arte do Estado"? Como medir as possíveis influências ou coincidências entre as ideias desses autores e o modus operandi de governantes no Brasil colonial? A partir de duas experiências, o artigo situa as práticas de governo e ideias de dois homens de poder no âmbito da discussão sobre a conservação do príncipe, imortalizada por Maquiavel. Primeiramente, pelo governo de D. Vasco Mascarenhas, $1^{\circ}$ conde de Óbidos e vice-rei (1663-1667), com suas estratégias para a manutenção e o incremento do governo-geral do Estado do Brasil. Em seguida, pelo exame do discurso sobre a revolta ocorrida em Vila Rica em 1720, atribuído a D. Pedro Miguel de Almeida Portugal, então futuro $3^{\circ}$ conde de Assumar (depois, $1^{\circ}$ marquês de Alorna), governador da capitania de São Paulo e Minas do Ouro (1717-1720). Busca-se aí refletir sobre a cultura política subjacente ao texto, no qual Maquiavel foi apenas uma vez lembrado, pejorativamente, pelo termo "maquiavelismos", próprio aos motins. Mas muitas outras referências foram invocadas no documento para justificar pela letra as ações violentas praticadas. ${ }^{7}$

\section{O conde de Óbidos na América portuguesa}

Em junho de 1663, o conde de Óbidos chegou à América do Sul como vice-rei do Brasil. Outrora governador de várias praças portuguesas e vice-rei no Estado da Índia (1652-1653), o conde afirmava ter sido enviado por D. Afonso VI para dar uma "nova forma ao governo deste Estado", restituindo-o de "tudo o que a variedade dos tempos lhe ocasionou ir perdendo". Após sua chegada, ele escrevia que todas as coisas teriam "diferentes termos" e todo o governo estaria "sujeito às minhas ordens". ${ }^{9}$ Mas as queixas contra as suas ações foram rapidamente

\footnotetext{
'Luís Reis Torgal; Rafaella Longobardi Ralha (orgs.), João Botero. Da razão de Estado, Tradução de Rafaella Longobardi Ralha, Coimbra, Inic, 1992 [1589], p. 1; Saúl Martínez Bermejo, Translating Tacitus: the reception of Tacitu's works in the vernacular languages of Europe, $16^{\text {th }}-17^{\text {th }}$ centuries, Pisa, Plus, 2010, p. 11-15.

${ }^{7}$ Laura de Mello e Souza (org.), Discurso histórico e político sobre a sublevação que nas Minas houve no ano de 1720, Belo Horizonte, Fundação João Pinheiro, 1994, p. 121.

${ }^{8}$ Carta, 05/12/1663, Biblioteca Nacional do Brasil (BNB), Documentos Históricos (DH), vol. IX, 1929, p. 133-137.

${ }^{9}$ Carta, 06/09/1663, BNB, DH, vol. IX, 1929, p. 123-124.
} 
ao conhecimento do Conselho Ultramarino. Segundo elas, o governador não cumpria os provimentos de cargos e ofícios feitos pelo rei. Embora os vassalos recebessem de D. Afonso VI o direito de ocupação temporária (serventia) ou a propriedade de um ofício, o vice-rei negava-lhes a sua posse, substituindo os indivíduos escolhidos pelo monarca por seus clientes e homens de confiança.

As ações do novo governador do Brasil produziram impactos na conquista ultramarina americana e no reino europeu. Sua obstrução das mercês régias desequilibrava a justiça distributiva do monarca e o processo de remuneração dos vassalos, gerando queixas ao reino. Alguns súditos pareciam estar cientes dos excessos do vice-rei e foram a Portugal reivindicar suas mercês, como Álvaro de Azevedo, provido pelo monarca no cargo de mestre-de-campo numa companhia da Bahia em 1663. Após viajar de Portugal ao Brasil, Azevedo teve sua patente negada pelo conde de Óbidos. O mestre-de-campo então retornou ao reino para queixar-se do vice-rei no Conselho Ultramarino, solicitando o cumprimento das ordens régias. Em Lisboa, Azevedo acusou duramente o conde de Óbidos e seus procedimentos. ${ }^{10}$

\section{Opiniões forjaram o "maquiavelismo", vocábulo que denunciava o uso de práticas políticas maliciosas pelos governantes para permanecerem no poder}

A questão dos provimentos desagradou também o tribunal da Relação do Estado do Brasil, a mais importante instituição de justiça nessa conquista. Em novembro de 1663, os ministros da Relação escreveram a D. Afonso VI, indignados com os provimentos feitos pelo conde de Óbidos nos cargos de médico e cirurgião do tribunal. Segundo a Relação, em lugar dos escolhidos pelos ministros em eleições internas, o conde provera outros indivíduos da sua confiança, usurpando a jurisdição do respeitável tribunal. ${ }^{11}$ Ademais, em junho de 1664, o desembargador Manuel de Almeida Peixoto escreveu ao monarca denunciando as ações do conde de Óbidos. Segundo Peixoto, o vice-rei, além de negar-lhe a posse no cargo de procurador da Coroa e da Fazenda Real, ameaçara-lhe de prisão e de envio ao reino. ${ }^{12}$ Cerca de dois meses depois, o chanceler Jorge Seco de Macedo escreveu ao monarca criticando o conde de Óbidos por sua conduta com os ministros da Relação, pelo não cumprimento das ordens régias e por perseguir todos os seus descontentes. ${ }^{13}$

Ante as críticas, o vice-rei tomou providências contra os seus acusadores. Nos dois últimos anos do seu mandato, o conde de Óbidos ordenou a prisão

\footnotetext{
${ }^{10}$ Consulta, 22/11/1663, Arquivo Histórico Ultramarino (AHU), Conselho Ultramarino Avulsos (CUA), Bahia, Luísa da Fonseca (LF), caixa 17, doc. 1972.

${ }^{11}$ Carta, 30/11/1663, AHU, CUA, Bahia, LF, caixa 17, doc. 1983

${ }^{12}$ Carta, 06/06/1664, AHU, CUA, Bahia, LF, caixa 18, doc. 2019

${ }^{13}$ Carta, O4/08/1664, AHU, CUA, Bahia, LF, caixa 18, doc. 2019; Stuart Schwartz, Burocracia e sociedade no Brasil colonial: a suprema corte da Bahia e seus juízes 1609-1751, Tradução de Maria Helena Martins, São Paulo, Perspectiva, 1979
} 
de sete indivíduos, que remeteram à Coroa papéis criticando seus procedimentos. Em julho de 1665, o ex-provedor-mor da Fazenda, Lourenço de Brito Correa, seu filho e mais três capitães foram presos na Bahia e enviados ao reino sem provas. O conde de Óbidos justificou as prisões acusando-os de conspirarem contra seu governo. Conforme o vice-rei, os supostos conjurados, liderados por Lourenço Correa e pelo chanceler da Relação, Jorge Seco de Macedo, enviaram ao reino papéis contra ele, enfraquecendo sua reputação. Após a partida da frota com os cinco suspeitos, o vice-rei anunciou a descoberta de outros conspiradores, o principal deles sendo o já citado desembargador da Relação, Almeida Peixoto. Segundo o conde de Óbidos, Manuel Peixoto, o abade do mosteiro de São Bento da Bahia, e outros seculares ou eclesiásticos também enviaram ao reino papéis contra seu governo, sendo cúmplices diretos dos primeiros conjurados. Em decorrência, o vice-rei iniciou uma perseguição aos novos opositores. ${ }^{14}$

Ameaçado pelo vice-rei, em agosto de 1665, o desembargador afastou-se de suas funções na Relação, retirando-se para o colégio da Companhia de Jesus da Bahia. Pouco depois, o vice-rei suspendeu os rendimentos de Peixoto. ${ }^{15}$ Acossado pelo conde de Óbidos, o desembargador então escreveu a D. Afonso VI denunciando os abusos cometidos pelo vice-rei do Brasil. Segundo ele, o conde perseguia todos os oponentes ao seu governo, até mesmo os sacerdotes que o criticavam abertamente em seus sermões. Ele teria também humilhado o chanceler Lourenço de Brito Correa em sua prisão, pois quando este foi conduzido pelos soldados à nau que o levaria ao reino, foi obrigado a passar pelo centro da cidade, para seu castigo ser visto por todos. O conde de Óbidos teria ainda enviado à residência de Correia homens armados com espingardas e arcos, que efetuaram disparos em direção a sua casa. ${ }^{16} \mathrm{O}$ vice-rei ordenou ainda outras prisões. Em meados de 1665, mandou encarcerar o já mencionado mestre-de-campo Álvaro de Azevedo. Como vimos, ele viajara a Portugal para queixar-se do vice-rei. Quando voltou à conquista americana, o mestre-decampo viu sua sorte piorar, com sua prisão no morro de São Paulo, na Bahia. ${ }^{17}$

Em maio de 1666, o secretário do Estado do Brasil, Bernardo Vieira Ravasco, também foi preso por ordem do vice-rei. Ravasco era irmão do padre Antônio Vieira e secretário do Estado do Brasil desde 1646. No reinado de D. João IV, teve grande prestígio na Corte lisboeta por suas relações familiares e função de secretário de Estado. Apesar de ainda atuar na secretaria de Estado no reinado de D. Afonso VI, Ravasco parecia não gozar mais da mesma importância. Assim, o secretário teve seu salário e patrimônio contestados. ${ }^{18}$ Preso por motivos desconhecidos, ele escreveu ao monarca e ao seu valido solicitando a sua

\footnotetext{
${ }^{14}$ Carta, 06/08/1665, AHU, CUA, Bahia, LF, caixa 18, doc. 210.

${ }^{15}$ Portaria, 25/08/1665, BNB, DH, vol. VII, 1929, p. 229-230.

${ }^{16}$ Carta, 25/09/1665, AHU, CUA, Bahia, LF, caixa 18, doc. 2110.

${ }^{17}$ Carta, 31/07/1666, AHU, CUA, Bahia, LF, caixa 19, doc. 2145.

${ }^{18}$ Pedro Puntoni, "Bernardo Vieira Ravasco, secretário do Estado do Brasil. Poder e elites na Bahia do século XVII", Novos Estudos Cebrap, n. 68, 2004, p. 107-126.
} 
liberdade, mas não obteve resposta. O secretário acusava o conde de Óbidos de descaminhos na Fazenda Real e de perseguição. ${ }^{19}$

Conforme Evaldo Cabral de Mello, o conde de Óbidos também influenciou na prisão e no envio ao reino do governador de Pernambuco, Jerônimo de Mendonça Furtado. ${ }^{20} \mathrm{O}$ governador, inimigo político e grande crítico do poder do vice-rei, desde o início do seu governo, rejeitou a sua autoridade. Em outubro de 1666, meses antes do fim do triênio de Furtado, os oficiais da câmara de Olinda escreveram ao conde comunicando a prisão de Mendonça Furtado. Quando comentou essa "novidade", o vice-rei demonstrou surpresa com a ação dos camaristas, afirmando não imaginar que seu governo testemunhasse "um desalumbramento, e desordem tão grande". ${ }^{21}$ Apesar da repreensão escrita, o conde de Óbidos não tomou qualquer medida contra os representantes da câmara. Com o governador deposto e a caminho do reino, não havia possibilidade de restituí-lo ao cargo. A deposição de Furtado assinalou o fim de suas investidas para o controle das regiões vizinhas a sua capitania, bem como de sua afronta ao poder do conde de Óbidos. Quando o vice-rei escreveu aos oficiais da câmara de Penedo sobre estes não cumprirem suas ordens por medo do governador deposto, em tom sarcástico lembrou-lhe que eles estavam livres "da desculpa, que vossas mercês davam de que por medo do governador [...] se não atreviam a dar cumprimento ao que eu mandava".22

Mesmo que o conde de Óbidos tivesse a aprovação do rei e seu ministro, o conde de Castelo Melhor, as críticas enfraqueciam seu governo e reputação. Além das queixas contra suas práticas no provimento dos ofícios, o conde não apresentou provas justificando as prisões efetuadas. Mas, com o fim de seu governo em junho de 1667, o conde de Óbidos voltou ao reino no ano seguinte sem qualquer punição. Em 1672, os ministros do Conselho Ultramarino averiguaram seus procedimentos no governo do Brasil, considerando-o inocente. ${ }^{23}$ O conde de Óbidos voltou então à casa real, servindo na Corte como estribeiromor da rainha Maria Francisca Isabel de Saboia, até morrer em 1678.

\section{Conde de Óbidos maquiavélico?}

Como interpretar esse governo à luz das discussões sobre a arte do Estado e os argumentos de Maquiavel? Conforme o secretário florentino, se um governante desejasse manter-se poderoso, era necessário "aprender a poder não ser bom e a se valer ou não disto segundo a necessidade". ${ }^{24}$ Desse modo, um príncipe não

\footnotetext{
${ }^{19}$ Carta, 1O/O4/1667, AHU, CUA, Bahia, LF, caixa 19, doc. 2209.

${ }^{20}$ Evaldo Cabral de Mello, A fronda dos mazombos: nobres contra mascates, Pernambuco, 1666-1715, Rio de Janeiro, Editora 34, 2003 [1995], p. 31.

${ }^{21}$ Carta, 07/10/1666, BNB, DH, vol. IX, 1929, p. 262.

${ }^{22}$ Carta, 06/11/1666, BNB, DH, vol. IX, 1929, p. 263.

${ }^{23}$ Parecer, O4/05/1672, AHU, CUA, Bahia, LF, caixa 21, doc. 2.467; Consulta, O4/05/1672, AHU, CUA, Bahia, LF, caixa 21, doc. 2.466; Consulta, 06/08/1674, AHU, CUA, Bahia, LF, caixa 22, doc. 2.597.

${ }^{24}$ Nicolau Maquiavel, O príncipe, Tradução de Olívia Bauduh, São Paulo, Nova Cultural, 1999 [1513], cap. XV, p. 73.
} 
poderia cumprir literalmente todas as regras do bom governo, pois era muitas vezes "forçado" a agir contra a "caridade, a fé, a humanidade, a religião". 25

Na América portuguesa dos séculos XVII e XVIII, há exemplos de governadores confirmando essas premissas, em nome da preservação da conquista ou de suas ambições. A violência era usada por eles para a aquietação da res publica, com o castigo público imposto a revoltosos e amotinados. ${ }^{26} \mathrm{O}$ Brasil colonial também testemunhou abusos dos governadores, ao castigarem os vassalos sem evidências - excessos causados muitas vezes por ambições pessoais dos governantes, motivações políticas ou rixas familiares. Um expediente bastante usado era a prisão e o envio ao reino do suposto culpado para seu recolhimento nas prisões de Lisboa. ${ }^{27}$

As práticas de governo do conde de Óbidos permitem uma aproximação desse caso às reflexões de Maquiavel. À maneira do modelo de príncipe elaborado pelo autor, o conde de Óbidos também se valeu do seu poder, agindo em função dos seus interesses. No provimento dos ofícios, o vice-rei decidia por conta própria quem seria contemplado, desrespeitando as prerrogativas do Conselho Ultramarino e a autoridade régia. Ademais, o conde de Óbidos priorizava os seus escolhidos em detrimento dos vassalos nomeados pelo monarca. Em seu governo, ele prendeu, desterrou e perseguiu opositores sem provas concretas. Como explicar esse pragmatismo político? Seria ele um daqueles nobres leitores de Maquiavel? Apesar da falta de registros documentais acerca da relação do vice-rei com os textos, uma breve análise de ideias e conceitos presentes nas suas cartas permite refletir sobre as origens teóricas de suas ações.

De formação católica e militar de carreira, o conde de Óbidos era um fidalgo português seiscentista, que conciliava assuntos políticos e fé particular. Tal aspecto era observado em diversos governantes europeus à época, bem como nos espaços das conquistas ultramarinas portuguesas. Apesar da importância da religião e de seus valores na política ibérica seiscentista, a devoção particular dos governantes não os impedia de atuar pragmaticamente, usando a força quando necessário. No caso do conde de Óbidos, esse vigor foi observado em várias circunstâncias. Em carta ao governador de Pernambuco, Francisco de Brito Freire, sobre uma expedição de entrada no quilombo dos Palmares, ele defendeu a necessidade de agir com "todo o rigor" contra os rebeldes do mocambo, pois, ante os fracassos das expedições anteriores, era preciso usar remédios fortes na empreitada, preservando a reputação das armas régias. Conforme o vice-rei, quando o responsável pela expedição constatasse a resistência de escravos fugidos, deveria "abrasar" a população, consumindo tudo "de maneira que não fique mais que as memórias de sua destruição.... O conde também alertou Brito Freire sobre a necessidade de o capitão responsável pela expedição estar atento aos quilombolas rendidos às tropas reais. Assim, agiria

${ }^{25}$ Nicolau Maquiavel, O príncipe, Tradução de Olívia Bauduh, São Paulo, Nova Cultural, 1999 [1513], cap. XVIII, p. 111. ${ }^{26} \mathrm{Como}$ na revolta contra Salvador Correia no Rio de Janeiro em 1660. Antonio Filipe Pereira Caetano, Entre a sombra e o sol: a revolta da cachaça e a crise política fluminense (Rio de Janeiro, 1640-1667), Maceió, Q-Gráfica, 2009.

${ }^{27}$ Carta, O2/09/1648, BNB, DH, vol. LXV, 1944, p. 341; Carta, 27/08/1649, BNB, DH, vol. LXV, 1944, p. 346-347. 
de forma justa, não faltando "à piedade católica, mas nem à obrigação militar, pois na clemência se facilita o rendimento". 28

Além desse pragmatismo próprio dos governadores das conquistas, as ações do conde de Óbidos parecem ter sido influenciadas pelo tipo de governo e pela conjuntura política vigente no reino. As reclamações sobre o vice-rei em seu controle do provimento dos cargos no Brasil assemelhavam-se às feitas contra o valido do rei português, o conde de Castelo Melhor, no reino no mesmo período. Desde sua ascensão ao poder em 1662, Luís de Vasconcelos e Sousa nomeara seus aliados para ofícios da casa real e tribunais da monarquia. Nesse sentido, o conde de Óbidos reproduzia na América portuguesa o governo de feituras vigente no reino, aproximando-se do estilo de poder implementado pelo escrivão da puridade de D. Afonso VI, ${ }^{29}$ com uma cultura política distante do exemplo de governante ideal difundido pela literatura tradicional de espelhos de príncipes. Tal afinidade talvez explique a sua permanência no governo colonial cerca de um ano além do triênio habitual, não obstante a oposição do Conselho Ultramarino e as queixas contra os seus procedimentos. Apesar das semelhanças, deve-se evitar a interpretação do conde de Óbidos como um simples executor da política do valido Castelo Melhor e atentar para a influência de suas motivações pessoais e a necessidade de manter sua posição de governante.

\section{Conforme o secretário florentino, se um governante desejasse manter-se poderoso, era necessário "aprender a poder não ser bom e a se valer ou não disto segundo a necessidade"}

A experiência pessoal do conde de Óbidos também foi determinante para o seu "maquiavelismo", pois os problemas de sua passagem pela Índia tiveram um papel central em seu comportamento político diante do governo brasileiro. As ameaças recebidas na Ásia, sua deposição como vice-rei em Goa e o enfrentamento do cárcere marcaram sua trajetória. Era preciso não repetir os mesmos erros do passado. Desse modo, D. Vasco Mascarenhas chegou ao Brasil com a experiência da Índia em mente, conforme sugerem algumas passagens de suas cartas. Em missiva a frei João de Cristo, ao comentar as arribadas no Brasil de navios vindos da Índia, o vice-rei queixou-se da presença constante dos assuntos indianos na sua vida. ${ }^{30}$ Quando explicou ao governador de Pernambuco o problema da incerteza da posição dos governantes, ele deu os exemplos

\footnotetext{
${ }^{28}$ Carta, 09/09/1663, BNB, DH, vol. IX, 1929, p. 127-128.

${ }^{29}$ Vinícius Orlando de Carvalho Dantas, O conde de Castelo Melhor: valimento e razões de Estado no Portugal seiscentista (1640-1667), Dissertação de Mestrado, Universidade Federal Fluminense, Niterói, 2009.

${ }^{30}$ Carta, 11/06/1665, BNB, DH, vol. IX, 1929, p. 238-239.
} 
da sua deposição do governo de Goa e da execução de Carlos I Stuart. ${ }^{31}$ Em 1665, como vimos, o conde prendeu e enviou ao reino cinco indivíduos queixosos dos seus procedimentos. A justificativa para punir antecipadamente a suposta conspiração era evitar o mesmo desfecho do seu governo na Índia, preservando-se como governante. Em suas acusações ao líder do pretenso motim, afirmou que agira incentivado pela negligência da Coroa em relação ao castigo das rebeliões no império português, à maneira da não punição dos culpados por sua deposição no governo da Índia. ${ }^{32}$ Portanto, o conde de Óbidos estava ciente da necessidade de atuar objetivamente, em nome da conservação da conquista ultramarina ou por motivos particulares. Os quatro anos de seu governo no Brasil testemunharam essas situações. Embora haja interseções entre as ações do conde e o modelo principesco de Maquiavel, seu "maquiavelismo" parecia derivar mais da sua experiência pessoal: a vivência no Estado da Índia ensinou-lhe a melhor forma de manter sua posição de governante.

Portanto, a conduta do vice-rei foi influenciada por três elementos principais: a necessidade de pragmatismo político do governante de uma conquista, devendo agir de forma enérgica quando necessário, a sintonia com o governo reformista do conde de Castelo Melhor, garantindo-lhe maior margem de intervenção e a experiência anterior no vice-reinado da Índia, onde o conde foi deposto e enfrentado pelas elites locais. Mediante a prática política, o vice-rei assimilava a ideia maquiaveliana de que, para manter-se no poder, devia controlar instituições e afastar os oponentes. $\mathrm{Na}$ época moderna, se as ideias de Maquiavel, Tácito e os debates sobre as razões de Estado foram fundamentais para orientar homens poderosos, a experiência e o conhecimento alcançados pela prática de governo igualmente foram importantes. Mas o saber e as opinões dos governadores ultramarinos também foram registrados em textos para justificarem suas ações políticas. O documento a ser analisado em seguida é paradigmático dessa chave de leitura.

\section{O conde de Assumar e a revolta de 1720}

Nascido em Portugal em 1688, D. Pedro Miguel de Almeida Portugal provinha da nobreza em destaque desde a ascensão da dinastia Bragança em 1640. Quando adolescente, ele acompanhou o pai à Catalunha, na Guerra de Sucessão da Espanha (1701-1713), lá lutando por vários anos e tendo chegado a general-de-batalha. Após a guerra, os Almeidas hipotecaram seus bens para saldar dívidas contraídas na permanência no exterior. A necessidade de levantar fundos talvez explique em parte a nomeação de D. Pedro Miguel em 1717 para o governo da capitania de São Paulo e Minas

${ }^{31}$ Carta, O5/12/1663, BNB, DH, vol. IX, 1929, p. 133-137.

${ }^{32}$ Carta, 06/08/1665, AHU, CUA, Bahia, LF, caixa 18, doc. 2100. 
do Ouro, aos 29 anos de idade. ${ }^{33}$ Formado na guerra e nas letras europeias, ele chegou às Minas para instaurar as casas de fundição do ouro e reforçar a cobrança do quinto, num contexto fundamental para a monarquia lusa, mas deveras conflituoso ao seu governo, pois nele grassavam descontentamentos, alianças volúveis e grupos em disputa. Embora tenha estranhado o ambiente colonial, o conde negociou e compôs com líderes locais. Eles eram ambíguos agentes da Coroa e de si mesmos, reinóis - ou emboabas envolvidos no comércio interno e/ou na mineração, alguns deles senhores de escravos, fazendas e lavras. ${ }^{34}$

Mas a sedição contra os impostos e taxas, que reclamava também do poder da câmara e dos dragões das tropas pagas - substituindo as ordenanças dos potentados locais - , reivindicava ainda o controle sobre a aferição do ouro. Ela desenvolveu-se mediante estratégias de intimidação ao governador e ao ouvidor e por arruaças de mascarados, sobretudo em Vila Rica. Acuado em seu palácio na vila vizinha de Ribeirão do Carmo, sem apoio dos principais que aceitavam as demandas dos revoltosos, conquanto sem violência, o futuro conde em princípio acatou as reivindicações, fingindo perdoar o movimento e substituindo o ouvidor. O conde de Assumar passou então a ser pressionado para deixar o governo, enquanto o potentado local, Pascoal da Silva Guimarães, distribuía novos cargos em Vila Rica. Entretanto, munindo-se de um espião, D. Pedro Miguel tomou providências para reprimir esse terceiro motim que já enfrentava nas Minas - os dois primeiros permaneceram impunes. Mandou, assim, montar a tropa de dragões e parte dela deveria fechar o caminho para Vila Rica. Além disso, prendeu os homens-chave do movimento, conduzidos ao Rio de Janeiro ou para a cadeia de Vila do Carmo, alguns depois para Lisboa. Enfim, em julho de 1720, D. Pedro Miguel entrou em Vila Rica, com as principais figuras da vila vizinha, os dragões e aproximadamente 1.500 negros. Ordenou incendiar as casas de Silva Guimarães. E, após um “julgamento sumário” — sem montar junta de justiça com o ouvidor ou qualquer magistrado e sem consultar ao rei -, mandou enforcar e esquartejar Felipe dos Santos, cometendo, assim, falta grave ante a monarquia.

O Discurso histórico e político sobre a sublevação que nas Minas houve no ano de 1720 foi atribuído a D. Pedro Miguel de Almeida Portugal e aos jesuítas José Mascarenhas e Antonio Correia, seus apaniguados, como peça de defesa por essa infração cometida pelo nobre português. Para captar a cultura política desse registro como suporte para as ações e o poder do futuro conde de Assumar, além de entender suas possíveis doses de continuidade e/ou heterodoxia em relação a seu contexto imediato, faz-se antes

\footnotetext{
${ }^{33}$ Diogo Barbosa Machado, Bibliotheca Iusitana hiftorica, critica e cronológica, tomo 3, Lisboa, Ignacio Rodrigues, 1752, p. 552-553; Laura de Mello e Souza (org.), Discurso histórico e político sobre a sublevação que nas Minas houve no ano de 1720, Belo Horizonte, Fundação João Pinheiro, 1994, p. 28-36.

${ }^{34}$ Alexandre Torres Fonseca, "A revolta de Felipe dos Santos", In: Maria Efigênia Lage de Resende; Luiz Carlos Villalta (orgs.), História de Minas Gerais: as Minas setecentistas, vol. 1, Belo Horizonte, Autêntica/Linha do Tempo, 2007, p. 549-566; Laura de Mello e Souza (org.), Discurso histórico e político sobre a sublevação que nas Minas houve no ano de 1720, Belo Horizonte, Fundação João Pinheiro, 1994, p. 59-139.
} 
necessário cotejar o tempo de atuação desse nobre no âmbito da monarquia portuguesa. Estudos seminais mais centrados no século XVII caracterizam a monarquia portuguesa com vários espaços decisórios e instâncias normativas, denotando uma autonomia político-jurídica de corpos, magistrados e instituições, além de conferir a seu governo um perfil policêntrico. Nessa visão, a Coroa seria um agregado de órgãos e interesses, e não um polo homogêneo de intervenção social, comportando instâncias concorrentes e conflitos de jurisdição. ${ }^{35}$

Contudo, nas primeiras décadas do reinado de D. João V, ter-se-iam dado mudanças na forma de tramitar as matérias no reino e no modo de governar o Brasil. Desde o fim do século XVII, o poder monárquico português teria sofrido um processo de centralização, indicado, por exemplo, pela não convocação das Cortes, ou pelo ostracismo do Conselho de Estado, substituído por um círculo restrito de conselheiros régios, mormente secretários. Para Nuno Gonçalo Monteiro, essa mutação silenciosa da "monarquia barroca" - com novos desenhos do centro e seus vínculos com os poderes periféricos - não foi linear. O autor recupera a revitalização de instituições tradicionais como as Cortes no processo que opôs a restauração constitucional após 1640, em relação ao reformismo anterior do conde-duque de Olivares. Mas passado o tempo de guerra com Espanha e a disputa de facções políticas, marcadas por episódios como o governo de Castelo Melhor, voltou a triunfar um modelo político distinto do pluralismo corporativo que, no entanto, prevalecera nos anos imediatamente posteriores à entronização dos Braganças e no período seguinte à deposição de D. Afonso VI. ${ }^{36}$

$\mathrm{O}$ historiador reage, assim, à ideia de continuidade institucional e política na monarquia portuguesa. Após a estabilização da dinastia em 1668, houve uma nova configuração de centros de poder, coincidente com a afirmação de elites sociais. Ao fim do século XVII, os titulares e muitos senhores de terras e comendadores residiam em Lisboa, distantes dos tempos da Corte ducal em Vila Viçosa. Com a consolidação aristocrática na regência de D. Pedro, os grandes (condes, marqueses e duques) distinguiam-se da fidalguia provincial. A maioria dos ofícios superiores do reino seria exercida pela primeira nobreza da Corte, à exceção dos magistrados e de cargos diplomáticos. Dessa forma, o pluralismo político e institucional diminuía e a polarização entre a Corte e as províncias era uma marca dessa monarquia, com pouca expressão dos corpos políticos intermédios.

As Cortes reuniram-se ainda quatro vezes e o tempo da regência e do reinado de D. Pedro II caracterizou-se por um funcionamento da administração central vigente ainda nos primeiros anos de D. João V. Esse perfil era

\footnotetext{
${ }^{35}$ António Manuel Hespanha, As vésperas do Leviathan: instituições e poder político. Portugal - séc. XVII, Lisboa, Almedina, 1994; Pedro Cardim, 'Administração e governo': uma reflexão sobre o vocabulário do Antigo Regime”, In: Maria Fernanda Bicalho; Vera Lúcia Amaral Ferlini (orgs.), Modos de governar: idéias e práticas políticas no império português. Séculos XVI a XIX, São Paulo, Alameda, 2005, p. 45-68.

${ }^{36}$ Nuno Gonçalo Monteiro, "A consolidação da dinastia de Bragança e o apogeu do Portugal barroco (16681750)", In: José Mattoso (dir.); António Manuel Hespanha (org.), História de Portugal: o Antigo Regime, vol. VIII, Rio de Mouro, Lexicultural, 2002, p. 267-282.
} 
diverso do adotado a partir da década de 1720, quando o rei passou a despachar com secretários de Estado à margem dos conselhos, sobretudo do Conselho de Estado. Não obstante, o período teria alguns aspectos comuns: a estabilidade dos alinhamentos políticos externos da dinastia e a diminuição das lutas intestinas, fazendo despontar o papel do rei. A política de mercês também sofreu uma inflexão importante, com menos títulos concedidos e a cristalização da elite nobiliárquica. Era, assim, um ciclo mais estável, fazendo reviver um modelo de tomada de decisões políticas, mesmo com o predomínio aristocrático e a restauração dos conselhos. No âmbito ultramarino, prevalecia a prioridade atlântica, apoiada na aliança inglesa e no relativo distanciamento luso dos conflitos europeus. A paz externa facilitava o domínio sobre as regiões coloniais.

Nesse sentido, as relações com o vizinho espanhol eram incontornáveis, pela proximidade territorial na Europa e na América do Sul, e eram altos os gastos para as embaixadas lusas no continente europeu, obtendo-se, enfim, a paridade de tratamento com outras monarquias católicas junto à Santa Sé, como antes de 1580. A elevação da capela real à patriarcal e o empenho na conquista do título cardinalício para o prelado de Lisboa acompanhavam uma redefinição da sociedade na Corte de D. João V, com conflitos de precedência e degredos de nobres. Os rituais e práticas de legitimação da monarquia foram reformulados nesse reinado, quando surgiam novos polos de representação, como o palácio-convento de Mafra, expressão visível desse investimento cultural. A representação espetacular do poder era uma marca do reinado de D. João V.

As academias literárias também fornecem subsídios para entender os vínculos entre saber erudito, estruturação do poder e conquistas ultramarinas portuguesas. A Academia Real da História Portuguesa, fundada em 1720 - da qual D. Pedro Miguel faria parte - , seria um caso especial, ao inaugurar uma vertente de conhecimento sobre a história do ultramar. Para Íris Kantor, surgia uma nova razão de Estado, mais secular em relação aos princípios político-teológicos que em outro tempo respaldaram a expansão lusa ${ }^{37}$ A necessária preservação das rotas comerciais entre o Oceano Índico e o Atlântico e a descoberta do ouro no Brasil conduziam a uma ação mais articulada da Coroa para defender sua soberania na América. Evidenciava-se, assim, uma nova percepção territorial, concretizada numa visão de conjunto sobre a geografia e a história do reino e do ultramar. ${ }^{38}$ Mas esse grande espaço vivia uma conjuntura delicada. A Guerra de

\footnotetext{
${ }^{37}$ Isabel Ferreira da Mota, A Academia Real da História: os intelectuais, o poder cultural e o poder monárquico no séc. XVIII, Coimbra, Minerva, 2003; Íris Kantor, Esquecidos e renascidos: historiografia acadêmica lusoamericana (1724-1759), São Paulo, Hucitec, 2004.

${ }^{38}$ /ris Kantor, Esquecidos e renascidos: historiografia acadêmica luso-americana (1724-1759), São Paulo, Hucitec, 2004, p. 267; Luciano Raposo de Almeida Figueiredo, "Antônio Rodrigues da Costa e os muitos perigos de vassalos aborrecidos (notas a respeito de um parecer do Conselho Ultramarino, 1732)", In: Ronaldo Vainfas; Georgina Silva dos Santos; Guilherme Pereira das Neves (orgs.), Retratos do império: trajetórias individuais no mundo português nos séculos XVI a XIX, Niterói, EdUFF, 2006, p. 187-203; Júnia Ferreira Furtado, Oráculos da geografia iluminista: Dom Luís da Cunha e Jean-Baptiste Bourguignon D’Anville na construção da cartografia do Brasil, Belo Horizonte, Editora da UFMG, 2012.
} 
Sucessão da Espanha - na qual lutara D. Pedro Miguel - influenciou as invasões francesas no Rio de Janeiro em 1710 e 1711, além de episódios da Guerra dos Mascates (1709-1711) em Pernambuco. ${ }^{39}$ A insurgência também foi pontuada por conflitos como a Guerra dos Emboabas em Minas, ${ }^{40}$ os motins do Maneta na Bahia em 1711 e a revolta de Vila Rica em 1720 foco do Discurso histórico... ${ }^{41}$

Nesse tempo de mutações políticas, o tema da aplicação do castigo devido foi recorrente na correspondência administrativa: por exemplo, o tratamento desigual dado por Pedro de Vasconcelos e Sousa aos dois motins na Bahia, quando o novo governador-geral voltou atrás no aumento de tributos e perdoou os rebeldes no primeiro deles, mas puniu duramente os chefes no segundo motim, com o degredo para a África. ${ }^{42}$ Também na Guerra dos Mascates, a busca da medida ao lidar com os sediciosos foi determinante no perdão final concedido aos senhores de engenho, ao interpretar as alterações de Pernambuco como discórdias e não como inconfidências. ${ }^{43}$ Redefinia-se, assim, o exercício do poder régio nos domínios ultramarinos, suas prerrogativas e seu governo, quando encarnado por representantes na América. Somente ao rei cabia castigar e perdoar os vassalos. ${ }^{44}$ Contudo, antes de maiores mudanças administrativas, na confluência desses fatores insere-se a atuação de D. Pedro Miguel de Almeida Portugal no governo da capitania de São Paulo e Minas do Ouro, bem como a elaboração do documento em tela.

\section{Palavras em ação}

Apesar de ser um documento estudado pela historiografia brasileira, principalmente para a consulta de fatos concernentes à revolta de 1720, é desejável empreender um novo exame do texto, de modo a entender mais ideias nele veiculadas e o seu uso político. Estamos ante um documento escrito elaborado com argumentos dispostos de forma eloquente sobre

\footnotetext{
${ }^{39}$ Maria Fernanda Bicalho, A cidade e o império: o Rio de Janeiro no século XVIII, Rio de Janeiro, Civilização Brasileira, 2003, p. 257-298; Evaldo Cabral de Mello, A fronda dos mazombos: nobres contra mascates, Pernambuco, 1666-1715, Rio de Janeiro, Editora 34, 2003 [1995].

${ }^{40}$ Adriana Romeiro, Paulista e emboabas no coração das Minas: idéias, práticas e imaginário político no século XVIII, Belo Horizonte, Editora da UFMG, 2008.

${ }^{4}$ Laura de Mello e Souza, "Motines, revueltas y revoluciones en la América portuguesa de los siglos XVII y XVIII", In: Enrique Tendeter; Jorge K. Lehuedé (orgs.), Historia general de América Latina, vol. IV, Madrid, Trotta/Unesco, 2000, p. 459-473; Luciano Raposo de Almeida Figueiredo, "O império em apuros. Notas para o estudo das alterações ultramarinas e das práticas políticas no império colonial português, séculos XVII e XVIII", In: Júnia Ferreira Furtado (org.), Diálogos oceânicos: Minas Gerais e as novas abordagens para uma história do império ultramarino português, Belo Horizonte, Editora da UFMG, 2001, p. 197-254; Carla Maria Junho Anastasia, Vassalos rebeldes: violência coletiva nas Minas na primeira metade do século XVIII, Belo Horizonte, C/Arte, 1998.

${ }^{42}$ Maria Fernanda Bicalho, "Inflexões na política imperial no reinado de D. João V", Anais de História de Alémmar, vol. VIII, 2007, p. 44-45.

${ }^{43}$ Evaldo Cabral de Mello, A fronda dos mazombos: nobres contra mascates, Pernambuco, 1666-1715, Rio de Janeiro, Editora 34, 2003 [1995], p. 433; Rodrigo Bentes Monteiro, O rei no espelho. A monarquia portuguesa e a colonização da América 1640-1720, São Paulo, Hucitec, 2002, p. 231-277.

${ }^{44}$ Maria Fernanda Bicalho, op. cit. p. 45.
} 
poder, glória, ações intempestivas e cálculo, conotados de modo positivo ou negativo ao tratar-se dos motins e conspirações. Nesse âmbito, talvez seja conveniente olvidar o suposto predomínio de legados culturais mais diretos, abrindo o campo para toda a sorte de influências e leituras. ${ }^{45}$ É o momento também de retirar o foco do enredo da revolta de 1720 e seus protagonistas para destacar outras referências nesse Discurso histórico...: aproximadamente 300 alusões, desde a Antiguidade até um tempo próximo a sua escrita, abrangendo um escopo considerável de ideias, valores e espaços. Mergulhemos, assim, mediante um levantamento quantitativo comentado, nesse mundo de autores (Quadro 1), personagens (Quadro 2) e situações "além das Minas", referidos no documento, que, em sua última versão impressa, apresenta 134 páginas.

\begin{tabular}{|c|c|c|}
\hline Autores & Quantidade de citações & Porcentagens (total de 132) \\
\hline Cícero & 15 & 11,36 \\
\hline Nicolas Caussin & 8 & 6,06 \\
\hline Tácito & 6 & 4,54 \\
\hline Camões & 6 & 4,54 \\
\hline Virgilio Malvezzi & 5 & 3,78 \\
\hline Francisco Sá de Miranda & 4 & 3,03 \\
\hline Ovídio & 4 & 3,03 \\
\hline Salústio & 4 & 3,03 \\
\hline Solórzano Pereira & 4 & 3,03 \\
\hline Bartolo de Saxoferrato & 3 & 2,27 \\
\hline Frei Juan Marques & 3 & 2,27 \\
\hline Platão & 3 & 2,27 \\
\hline Sêneca & 3 & 2,27 \\
\hline Outros & 64 & 48,48 \\
\hline
\end{tabular}

Observa-se nessa primeira contagem o vultoso número de autores citados e/ou identificados no documento, abrangendo suas duas partes: a primeira, mais narrativa da revolta, e a segunda, com justificativas para o castigo. ${ }^{46}$ Embora a segunda parte invoque mais autoridades, com 105 autores, 27 deles também são mencionados na primeira. E não havia maior referência no Discurso histórico... do que Marco Túlio Cícero, figura do fim da República romana. A biblioteca do marquês de Alorna possuía 14 volumes não discriminados de suas obras, mas ele possivelmente também fazia parte

\footnotetext{
${ }^{45}$ Luís Reis Torgal, Ideologia política e teoria do Estado na Restauração, Coimbra, Biblioteca Geral da Universidade de Coimbra, 1981-1982, 2 v.; Pedro Cardim, "Religião e ordem social. Em torno dos fundamentos católicos do sistema político do Antigo Regime”, Revista de História das Idéias, vol. 22, 2001, p. 133-174.

${ }^{46}$ Laura de Mello e Souza (org.). Discurso histórico e político sobre a sublevação que nas Minas houve no ano de 1720, Belo Horizonte, Fundação João Pinheiro, 1994, p. 59-139; 140-193.
} 
da bagagem letrada de Antonio Correia e José Mascarenhas. No século XVIII e desde muito antes, Cícero era um argumento poderoso de autoridade e sua presença faz-nos lembrar a eloquência e o Discurso histórico..., concebido como uma peça retórica. Mas Cícero era igualmente homem de ação e governo, cônsul da República e membro do senado de Roma. O tema será aprofundado adiante, na tentativa de identificar uma linha mestra de ideias políticas presente no texto em análise.

O segundo autor mais presente no documento é o jesuíta francês Nicolas Caussin, no Discurso histórico... citado como Causino, ausente da carta ao bispo ou da biblioteca e inserido no âmbito do fortalecimento da oratória seiscentista na França. ${ }^{47}$ Caussin inspirava-se na prudentia ciceroniana, fazendo o orador adequar o ingenium, o assunto e as circunstâncias do auditório; Cícero também é associado ao ecletismo presente nos escritos desse jesuíta, que compreendiam uma tradição hieroglífica. Para esse confessor de Luís XIII, as nobrezas sacerdotal e de espada teriam acesso a essa linguagem sagrada. Como foi expresso no livro Corte santa, publicado primeiramente em 1638, cuja tradução espanhola é citada no Discurso histórico..., Caussin era também conhecido por seu rigor contra os jansenistas e, por suas menções no documento, defendia severidade e "império" diante de delitos, escândalos e insolências de gentes ásperas e rebeldes. Seria uma apropriação de ideias marginais desse autor, no repertório de livros dos secretários de Assumar? Ou o esoterismo dos livros de Caussin, presente em certas passagens do Discurso histórico..., teria o seu papel nessa cultura política? ${ }^{48}$

\section{Estamos ante um documento escrito elaborado com argumentos dispostos de forma eloquente sobre poder, glória, ações intempestivas e cálculo}

Em seguida, desponta no documento o "grande mestre dos príncipes", como o texto qualifica Tácito. ${ }^{49} \mathrm{Na}$ biblioteca de D. Pedro Miguel, figurava um volume dos Anais, em latim ou uma tradução, pois o historiador romano invadiu o mundo letrado e editorial europeu entre os séculos XVI e XVII. ${ }^{50}$ Sua análise sobre os imperadores romanos contém reflexões sobre

\footnotetext{
${ }^{47}$ Marc Fumaroli, L'âge de l'éloquence: rhétorique et "res literaria" de la Renaissance au seuil de l'époque classique, Paris, Albin Michel, 1994 [1980], p. 279-298.

${ }^{48}$ Laura de Mello e Souza (org.), Discurso histórico e político sobre a sublevação que nas Minas houve no ano de 1720, Belo Horizonte, Fundação João Pinheiro, 1994, p. 71; 98.

49/dem, Ibidem, p. 163.

50Saúl Martínez Bermejo, Translating Tacitus: the reception of Tacitu's works in the vernacular languages of Europe, $16^{\text {th }}-17^{\text {th }}$ Centuries, Pisa, Plus, 2010.
} 
o principado no tempo de Tibério, transformado em tirano também pelas ações do valido Sejano. Os vínculos entre tacitismo e maquiavelismo são complexos; os dois autores possuem vários pontos comuns nas suas formas de observar o poder. Contudo, Tácito - diferente de Maquiavel -, ao comentar de forma negativa os abusos da autocracia imperial, fornecia subsídios aos governos da época moderna sob as convenientes e prestigiosas vestes de um autor antigo, republicano e pagão. Invoca-se esse autor no Discurso histórico... em favor da prontidão e da celeridade ante as sedições por várias frases em latim, algumas delas junto a Salústio, por meio da pena do jurista espanhol Juan Solórzano Pereira. ${ }^{51}$

O Discurso histórico... enaltece também Luís de Camões, o poeta soldado ausente na carta escrita ao bispo e na biblioteca, com trechos d'Os lusíadas entremeando a narrativa, por vezes não referenciados. ${ }^{52}$ Os versos teriam valor ornamental e simbólico, ao invocarem a viagem de Vasco da Gama à Índia e as glórias dos portugueses notáveis, herdeiros de epopeias antigas, com heróis e deuses inspirados nas obras clássicas. Ao início do século XVIII, Camões teria expressivo papel nessa identidade lusófona, conferindo um tom épico e imperial ao documento. ${ }^{53}$

Ainda presente apenas no Discurso histórico..., há o "marquês Virgílio", ou Virgilio Malvezzi, ensaísta bolonhês traduzido nas principais línguas europeias e em latim. Em suas biografias políticas, em meio a um relato mais abstrato, engatavam-se algumas considerações, dando-se por supostos os dados do protagonista. ${ }^{54} \mathrm{O}$ conhecido Francisco de Quevedo admirava esses golpes de efeito e traduziu Il Romulo para o espanhol em 1632. Assim, o conde-duque de Olivares chamou Malvezzi a Madri em 1636 para celebrar os triunfos do seu regime, integrando-o em missões diplomáticas e conselhos da monarquia. ${ }^{55}$ No Discurso histórico..., o marquês Virgílio é invocado para tratar da reputação do príncipe, mais importante que o "estado" e a própria vida, sobre a inutilidade da lei sem força para castigar ou para afirmar a rebelião como igual crime, contra o príncipe ou o governador. ${ }^{56}$ Mas não apenas autores e livros seriam importantes para captar visões de mundo e poder no texto examinado.

\footnotetext{
${ }^{51}$ Laura de Mello e Souza (org.), Discurso histórico e político sobre a sublevação que nas Minas houve no ano de 1720, Belo Horizonte, Fundação João Pinheiro, 1994, p. 163-165; 172; Vinícius Orlando de Carvalho Dantas, O conde de Castelo Melhor: valimento e razões de Estado no Portugal seiscentista (1640-1667), Dissertação de Mestrado, Universidade Federal Fluminense, Niterói, 2009, p. 59-60; 70-71.

52Laura de Mello e Souza (org.), op. cit. p. 100; 147; 153; 156; 161-162.

53Vítor Aguiar e Silva (org.), Dicionário de Luís de Camões, São Paulo, Leya, 2011, p. 42-45; 341-345; 923-933.

${ }^{54}$ Mercedes Blanco, "Quevedo lector de Malvezzi", La Perinola. Revista de investigación quevediana, n. 8, 2004, p. 77-108. Disponível em: <http://hdl.handle.net/10171/5603>. Acesso em: 6 de janeiro de 2013.

55John H. Elliott, El conde-duque de Olivares, Tradução de Teófilo Lozoya, Barcelona, Crítica, 2004 [1986], p. 40; 594; 605; 629-632.

${ }^{56}$ Laura de Mello e Souza (org.), op. cit., p. 150; 172; 186; 189-190.
} 
Quadro 2. Personagens no Discurso histórico e político sobre a sublevação que nas Minas houve no ano de 1720

\begin{tabular}{|lcc|}
\hline Personagens & Quantidade de citações & Porcentagens (total de 134) \\
\hline Júpiter & 6 & 4,47 \\
\hline São Pedro & 5 & 3,73 \\
\hline Moisés & 4 & 2,98 \\
\hline Hércules & 3 & 2,23 \\
\hline Agesilau & 3 & 2,23 \\
\hline Catilina & 2 & 1,49 \\
\hline Constantino & 2 & 1,49 \\
\hline Apolo & 2 & 1,49 \\
\hline Augusto & 2 & 1,49 \\
\hline Felipe da Macedônia & 2 & 1,49 \\
\hline Júlio César & 2 & 1,49 \\
\hline Marte & 2 & 1,49 \\
\hline Maximiliano I & 2 & 1,49 \\
\hline Mercúrio & 2 & 1,49 \\
\hline Vulcano & 2 & 1,49 \\
\hline Proteu & 2 & 1,49 \\
\hline Outros & 91 & 67,9 \\
\hline
\end{tabular}

Na Roma antiga, Júpiter era o deus do dia, do céu, senhor do raio e do trovão, a mais importante divindade naquele panteão, com origem no patrimônio mítico comum dos povos indo-europeus, mas assumindo características particulares. Seu templo erguia-se no Capitólio. Sob sua proteção, os cônsules agradeciam-lhe a conservação da República e suas vitórias. Na época imperial, governantes identificavam-se como suas encarnações. ${ }^{57}$ Era uma forte alegoria de poder, ao simbolizar valores, mitos e fatos passados. Desde o Renascimento, gravuras e livros impressos europeus faziam releituras de Hesíodo, Horácio e Ovídio - autores citados no Discurso histórico... Nas bibliotecas régias de D. João V, pululavam estampas e livros com imagens (em forma escrita e/ou visual) de Júpiter e Hércules - os combates do semideus à hidra de Lerna e ao leão eram os preferidos do conde de Assumar para abordar os motins. ${ }^{58}$ No Discurso histórico..., Júpiter é invocado como deus passível de consentimento ou indignação na oração fulminada por Cícero contra Catilina, ao defender que fosse banido de Roma ou, numa associação equivocada, ao mencionar uma fábula de Esopo sobre "Júpiter" e a serpente — na verdade, Zeus. ${ }^{59}$ Mas impressionam

\footnotetext{
57Junito de Souza Brandão, Dicionário mítico-etimológico: mitologia e religião romana, Brasília, Editora da UnB; Petrópolis, Vozes, 2008 [1993], p. 189-193.

${ }^{58}$ Baltasar de Victoria, Teatro de los dioses de la gentilidad, vol. I, Barcelona, Juan Pablo Marti; Francisco Barnola, 1702, p. $92-95$ e vol. II, p. 78-85; Marie-Thérèse Mandroux-França (org.), Catalogues de la collection d'estampes de Jean V, roi de Portugal par Pierre-Jean Mariette, vol. II, gravuras 27 e 223, vol. III, gravura 200, Lisboa, Fundação Calouste Gulbenkian/Fundação Casa de Bragança; Paris, Bibliothèque Nationale de France, 1996

${ }^{59}$ Laura de Mello e Souza (org.), Discurso histórico e político sobre a sublevação que nas Minas houve no ano de 1720, Belo Horizonte, Fundação João Pinheiro, 1994, p. 139; 152; 157-158.
} 
no texto as inúmeras alusões a raios, trovões, tempestades e demais fenômenos climáticos, não raro usadas para definir o poder forte dos príncipes.

Da analogia pagã à cristã. As pontes entre os nomes de D. Pedro Miguel e São Pedro são recorrentes, algo comum nos sermões da época e na documentação laudatória da Academia Real da História Portuguesa — da qual o conde de Assumar faria parte a partir de 1736. Sabe-se que o conde celebrava o dia do santo, num mundo onde as palavras e as coisas andavam juntas. ${ }^{60} \mathrm{~A}$ utilização de exemplos bíblicos era um expressivo argumento de ordem moral, conferindo respeito ao documento como peça de defesa. Ademais, o texto teve a colaboração de dois clérigos. Nesse jogo de similitudes, Moisés foi mais próximo à personalidade pública do conde de Assumar, em suas manifestações de força, rigidez e punição a desordeiros, sobretudo no episódio concernente ao bezerro de ouro, mencionado ao fim do Discurso histórico... ${ }^{61} \mathrm{O}$ peso das figuras bíblicas citadas no texto é de aproximadamente 13\%, com equilíbrio entre o Antigo e o Novo Testamento e poucos exemplos egípcios ou persas. Em contrapartida, o mundo clássico faz-se presente com $53 \%$ de personagens do Discurso histórico..., divididos em gregos (6\%), romanos (22\%) e retirados de sua mitologia (25\%). O período medieval compreende apenas $4 \%$ das personagens citadas, enquanto o mundo moderno tem pouco mais de $25 \%$.

Estendendo essa tentativa de periodização e agrupamento ao conjunto de autores citados e/ou identificados, o predomínio do mundo clássico esboça-se mais: os autores bíblicos aparecem com 1,5\%, os gregos antigos com mais de $11 \%$ e os latinos pagãos com quase $36 \%$. Os escritos da patrística correspondem a $6 \%$ do documento, enquanto escolásticos, santos e juristas "medievais" somam 9\% em todo o Discurso histórico... Por fim, os autores da época moderna perfazem $36 \%$, num total de 132 remissões. E, se agrupamos por contextos e épocas todas as referências históricas do documento, compreendendo autores, personagens e situações, vemos, num total de 300, a Antiguidade greco-romana despontar com $48 \%$, as referências bíblicas com $8 \%$, a Idade Média com 9\% e a Moderna com $32 \%$.

Contudo, se o classicismo caracteriza uma tendência do texto analisado, o aspecto não seria exclusivo dessa fonte, constituindo um signo de erudição e autoridade inerente àquele tempo, valores presentes também na aristocracia lusitana letrada setecentista. Por outro lado, a contagem visando perceber o peso das referências a autores, personagens e situações portuguesas incluindo possessões ultramarinas - revela escassas menções ao mundo luso, atingindo apenas $8 \%$ do total de 300 referências históricas no documento, exceto o contexto da revolta nas Minas. Portanto, resta entrecruzar esse aspecto - o apreço aos referenciais clássicos - ao leque de situações históricas expostas no Discurso histórico..., a fim de perceber escolhas teóricas e empíricas e enveredar no cerne de sua argumentação.

\footnotetext{
60Michel Foucault, As palavras e as coisas: uma arqueologia das ciências humanas, Tradução de Salma Muchail, São Paulo, Martins Fontes, 2002 [1966], p. 23-61.

6'Laura de Mello e Souza (org.), Discurso histórico e político sobre a sublevação que nas Minas houve no ano de 1720, Belo Horizonte, Fundação João Pinheiro, 1994, p. 192-193.
} 


\section{Crimes e castigos}

O último cômputo efetuado refere-se a 33 situações históricas mencionadas no documento, demonstrativas da conduta a ser seguida na aplicação do castigo e na punição da rebelião. Nele, grosso modo, os episódios bíblicos atingem $12 \%$, a Pérsia antiga $6 \%$, a Grécia antiga $15 \%$, a Roma antiga $21 \%$ e a Europa medieval 3\%. Já as situações retiradas da época moderna abrangem $42 \%$, com metade desses últimos eventos mencionados ocorrida na Europa e metade no mundo colonial (espanhol e português). Assim, nesse caso, predominam os exemplos modernos sobre os antigos. Embora, desde o início de sua segunda parte, o Discurso histórico... aluda a essas situações modernas exemplares - como na menção ao ocorrido no quilombo dos Palmares,$-{ }^{62}$ as dez últimas páginas da sua mais recente edição impressionam por uma remissão massiva e ordenada, apesar de mesclada a poucos exemplos antigos ou frases de juristas medievais. Os episódios comentados nessas páginas podem ser agrupados nos blocos temáticos apresentados a seguir.

Em relação às guerras de religião na França, o texto lembra as inquietações em Marselha no reinado de Henrique III, quando o governador mandou enforcar os amotinados, sendo alguns atirados da janela do palácio. ${ }^{63}$ Também em meio ao predomínio da Liga católica em Paris, o duque de Mayenne mandou prender e garrotear os suspeitos de um assassinato, sendo seus corpos expostos ao público. ${ }^{64}$ Recupera-se ainda a conjuração de Amboise, quando a cavalaria real ateou fogo na vizinhança ${ }^{65}$ Essas informações foram retiradas da versão espanhola do livro do italiano Henrico Caterino D'Avila. ${ }^{66}$

Sobre a conjura Pazzi em Florença, o Discurso histórico... enfatiza a repressão à tentativa dessa família de banqueiros em tomar o senhorio de Lourenço de Medici em 1477, lembrando os corpos dependurados nas janelas do palácio do governo, entre eles, os do arcebispo de Pisa, de Francesco e de Giacomo de Pazzi. ${ }^{67}$

Na monarquia hispânica em 1521, o documento ressalta a revolta dos comuneros, debelada após serem violentamente castigados alguns dos seus

\footnotetext{
"2Laura de Mello e Souza (org.), Discurso histórico e político sobre a sublevação que nas Minas houve no ano de 1720, Belo Horizonte, Fundação João Pinheiro, 1994, p. 150-151.

63/dem, Ibidem, p. 181-182.

64/dem, Ibidem, p. 182; Arlette Jouanna et al., Histoire et dictionnaire des Guerres de Religion, Turim, Robert Lafont, 1998, p. 1088-1091.

${ }^{65}$ Laura de Mello e Souza (org.), op. cit. p. 183; Arlette Jouanna et al., op. cit. p. 647-648.

${ }^{66}$ Enrico Caterino Davila, Historia de las guerras civiles de Francia. Tradução e adições (de 1598 a 1630) de Basílio Varen de Soto, Antuérpia, Juan Bautista Verdussen, 1713, p. 17-20; 207-208; $397-398$.

${ }^{67}$ Laura de Mello e Souza (org.), op. cit. p. 182; Christopher Hibbert, Ascensão e queda da casa dos Medici: o Renascimento em Florença, Tradução de Hildegard Feist, São Paulo, Companhia das Letras, 1993 [1974], p. 107-118.
} 
principais "motores". ${ }^{68} \mathrm{Ou}$, no mesmo ano, na Nova Espanha, aludindo a uma sublevação contra Hernán Cortez, que entrou com seus guardas na casa do rebelde, sendo ele na mesma noite enforcado, com seu corpo exposto na janela. ${ }^{69}$ Em 1521, teria ainda ocorrido outro motim, não identificado, nas Canárias, quando os principais "cabeças" foram enforcados a mando do governador. ${ }^{70}$

Na monarquia portuguesa, o Discurso histórico... volta-se para a Guerra da Restauração (1640-1668) por meio da pena do conde de Ericeira, ao relatar as ações de D. Francisco de Souza em 1641, queimando a vila de Barrancos pela pouca constância de seus moradores na defesa da praça. A execução com fogo lembra um episódio da revolta de $1720 .{ }^{71}$ Em outro trecho, a comparação entre os dois contextos retorna, ao justificar-se a repulsa de uma violência maior, mediante o castigo antecipado imposto pelo futuro conde de Assumar, similar ao defendido pelo embaixador Francisco de Souza Coutinho sobre a libertação do infante D. Duarte de Bragança. ${ }^{72}$ Já em "Angola", no mesmo ano de 1521, ocorreu uma sublevação, logo castigada. ${ }^{73}$ No Brasil, em tempo próximo aos acontecimentos mineiros, o documento refere um crime em Sergipe no governo de D. João de Lencastre (16941702), quando um coronel pôs fogo na casa de Antônio de Faria. Por fim, o Discurso histórico... alude a uma sindicância do desembargador Belchior da Cunha Brochado no Rio de Janeiro por volta de 1688, que pôs fogo em oficinas de madeiras, bem como ao governo de Francisco Xavier de Távora (1713-1716), que mandou queimar a fazenda de José Gurgel. ${ }^{74}$

Chega-se, assim, ao momento de supor uma linha mestra de analogia na interpretação do Discurso histórico..., sem excluir seus demais sentidos e ressignificações. Essa acepção será procurada entre os exemplos romanos e, para tal, busca-se novamente Cícero, sobretudo o político e homem de ação, o cônsul da res publica que colocou o seu discurso, mediante quatro orações proferidas no senado, a favor do castigo sem julgamento formal para uma revolta. O episódio, pelo poder persuasivo de seu orador, tornar-se-ia paradigmático para os destinos de Roma. Em suma, em meados do século

\footnotetext{
${ }^{68}$ Laura de Mello e Souza (org.), Discurso histórico e político sobre a sublevação que nas Minas houve no ano de 1720, Belo Horizonte, Fundação João Pinheiro, 1994, p. 182-183; Antonio Miguel Bernal, Josep Fontana; Ramón Villares (orgs.), Historia de España: monarquía e império, vol. 3, Madrid, Crítica/Marcial Pons, 2007, p. 82-88.

${ }^{69}$ Laura de Mello e Souza (org.), op. cit. p. 183; Antonio de Solis, Historia de la conquista de Mexico: población, y progresos de la América setentrional, livro 5, Bruxelas, Francisco Foppens, 1704, p. 560-562; Tzvetan Todorov, A conquista da América: a questão do outro, Tradução de Beatriz Moisés, São Paulo, Martins Fontes, 1988 [1982], p. 112-113.

${ }^{70}$ Laura de Mello e Souza (org.), op. cit. p. 183

71/dem, Ibidem, p. 183-184; Luís de Menezes, História de Portugal Restaurado, tomo 1, Lisboa, João Galrão, 1679, p. 230.

${ }^{72}$ Laura de Mello e Souza (org.), op. cit. p. 187; Gustavo Kelly de Almeida, Herói em processo: escrita e diplomacia sobre D. Duarte de Bragança (1641-1649), Dissertação de Mestrado, Universidade Federal Fluminense, Niterói, 2011, p. 16; 22-23; 85-87.

${ }^{73}$ Laura de Mello e Souza (org.), op. cit. p. 183. Angola não existia no século XVI. Talvez o documento se reportasse ao Congo de Afonso I (1506-1543) e aos reinos vizinhos Loango ou Ndongo, com débil ocupação lusa.

74/dem, Ibidem, p. 185.
} 
I a.C., as questões decorrentes da expansão territorial romana refletiam-se no senado, onde os optimates, afinados às famílias patrícias, distinguiam-se dos popvlares, que compactuavam com a plebe. ${ }^{75}$ Lúcio Sérgio Catilina, um nobre outrora pretor em Roma e governador na África, após ser preterido em duas eleições consulares, juntou-se a Públio Lêntulo e outros e começou a conspirar, divulgando promessas entre os descontentes da capital e das províncias. A trama foi delatada a Cícero, um homo novus de família enriquecida, mas plebeia, que chegara ao poder em Roma por seus talentos políticos e oratórios.

\section{A península itálica ao início do século XVI também era um território tumultuado, com a difícil submissão dos habitantes e as ameaças de Espanha e França}

Em novembro de 63 a.C., Cícero proferiu um série de orações: no templo de Júpiter, com o próprio Catilina presente, conclamando-o a deixar Roma; ${ }^{76}$ depois, informando ao senado sobre o exílio do rebelde; em seguida, revelando a descoberta de um plano que incluía arregimentar soldados, massacrar os optimates e incendiar Roma, além de uma aliança com gauleses insatisfeitos com o jugo romano. Em dezembro, o senado reuniu-se para decidir a pena dos chefes da conjura. Na célebre sessão, Júlio César, então pontífice máximo, fez um discurso a favor da prisão perpétua para Lêntulo e seus sequazes. Mas Cícero, em sua quarta catilinária, defendeu a pena de morte a todos, dizendo ser esse o remédio mais eficaz para a República. A eficiente retórica de Cícero preparou o caminho para o discurso de Catão a favor da execução capital dos rebeldes, sem processo. Os discursos opostos de César e Catão foram depois reelaborados com a pena de Salústio, historiador protegido de César. ${ }^{77}$ No entanto, Cícero logo reescreveu e fez divulgar suas quatro catilinárias, conhecidas como sua grande ação política na defesa da pátria. Lêntulo e quatro outros líderes revoltosos foram estrangulados; Catilina morreu um mês depois em combate. Por sua intercessão a favor da pena capital aplicada aos presos, Cícero foi depois temporariamente exilado do senado e de Roma, em princípio, sem poder para medidas tão drásticas.

No Discurso histórico..., Cícero é invocado para defender o valor da fé pública como pedra fundamental da justiça; ou falar sobre o dever dos príncipes em

\footnotetext{
${ }^{75}$ Charles Matson Odahl, Cicero and the Catilinarian conspiracy, New York/London, Routledge, 2011. 76/dem, Ibidem, p. 272-274; Cícero, As catilinárias, Amilcare Carletti (org.), São Paulo, Leud, 2000 [1999]. 7ొLuciano Canfora, Júlio César: o ditador democrático, Tradução de Antonio Mendonça, São Paulo, Estação Liberdade, 2002 [1999], p. 81.
} 
resistir à multidão e aos dissolutos; ou para combater a impunidade nas conjurações de Roma, a fim de assegurar os valores da República, aplicando-se qualquer remédio na solução de algo; ou para advogar a causa da "necessidade" como sendo superior ao foro humano e legal. Quando as armas faziam calar as leis, devendo, assim, ser usadas pelo governante. ${ }^{78}$ Embora o nome de Catilina só seja escrito no Discurso histórico... por duas vezes, essas orações foram decisivas para dar o tom do documento que vilanizava os rebeldes em Minas à maneira dos conjurados romanos antigos, defendendo para eles uma punição mais forte do que a permitida pelos meios legais. Estamos, assim, ante discursos oriundos de dois contextos e tempos diversos, aproximados por meio do uso político do primeiro feito pelo segundo. Cícero proferiu sua oração para obter a pena máxima aos acusados; por sua vez, o Discurso histórico... foi redigido após a punição, ao vilanizar Pascoal da Silva Guimarães, Manuel Nunes Viana, Felipe dos Santos e os habitantes das Minas. Não há notícia da recepção do Discurso histórico... atribuído ao conde de Assumar, como manuscrito, no âmbito da monarquia portuguesa. Não se sabe por quem foi lido ou se influiu no destino de D. Pedro Miguel de Almeida em seu exílio da Corte após esse episódio. Nada se sabe até a aparição do documento ao fim do século XIX em Lisboa.

\section{Maquiavel dissimulado}

É o momento, então, de relacionar o uso e a cultura política desse texto às ideias de Maquiavel e outros autores sobre a arte dello Stato. Há várias inflexões que vinculam esse contexto e sua principal fonte documental ao âmbito de escrita d'O príncipe. A península itálica ao início do século XVI também era um território tumultuado, com a difícil submissão dos habitantes e as ameaças de Espanha e França. Se, após o tratado de Utrecht de 1715, as Minas estavam mais protegidas de invasões externas, o valor intrínseco do ouro conferia a Portugal sua necessária preservação da cobiça internacional, além do perigo dos motins. N'O príncipe e no Discurso histórico..., defendia-se a manifestação enfática do poder soberano em suas regiões: um príncipe mais temido que amado e belicoso, que mantivesse o seu "estado" não tanto por medidas administrativas - próprias de alguns Estados modernos europeus nos séculos XVII e XVIII, mas por assertivas ações personalizadas e impactantes frente aos súditos, preferindo as armas às leis. São essas as passagens do documento analisado mais próximas ao conhecido capítulo XVII do livro de Maquiavel, o qual disserta se ao príncipe é preferível ser amado ou temido:

Acabem de entender os príncipes que talvez aumentam os danos da república com a sua piedade, e que em certas ocasiões são mais piedosos, quanto mais severos; pois a severidade que castiga a alguns é piedade que absolve a muitos; [...] Nem como poderá

${ }^{78}$ Laura de Mello e Souza (org.), Discurso histórico e politico sobre a sublevação que nas Minas houve no ano de 1720, Belo Horizonte, Fundação João Pinheiro, 1994, p. 108; 145; 154; 158; 169; 175; 179; 181; 189. 
segurar-se e fazer confiança nos bons vassalos o príncipe que perdoa aos maus, quando é sem dúvida que perdoar aos maus é botar a perder os bons; e juntamente mostra a experiência que nada humilha e derruba tanto a insolência dos corações rebeldes como a formidável voz e horrorosa vista de um sucesso trágico. ${ }^{79}$

Não há que estranhar que ignorem os mineiros que há rei que domine este país, onde nunca foi visto o seu raio [...] porque se não punir as maldades, não é príncipe em realidade, é uma representação e sombra de príncipe. Pois é certo que o decoro real nem se vincula ao cetro, nem se anexa à coroa, avulta sim nos golpes do montante, no estrondo das artilharias, no tropel dos cavalos, e na multidão dos infantes, porque só onde se lhe temem as forças é despótica a Soberania... ${ }^{80}$

Entre a Florença dos Médicis e a Vila Rica da dinastia de Bragança, as inserções sociais e políticas de Maquiavel e do futuro conde de Assumar eram distintas nos momentos de redação dos dois textos. O primeiro era então um ex-secretário em dificuldades políticas; já o segundo, um nobre governador de capitania tentando justificar o seu mando intempestivo. Contudo, nem Maquiavel, nem D. Pedro Miguel, mediante seus escritos, intentaram resumir o perfil de um príncipe renascentista italiano ou o comportamento usual dos reis de Portugal em seus respectivos tempos. Como se sabe, o secretário florentino escreveu um pequeno livro, depois dedicado a Lourenço de Médici, publicado somente em 1532. E, até o presente, desconhece-se o destino do manuscrito em defesa do conde de Assumar na Corte dos Braganças.

Como vimos, D. Pedro Miguel de Almeida Portugal, ao tempo da revolta de 1720, respondeu por uma vertente de governo mais arbitrário na monarquia portuguesa, embora também fosse capaz de pactuar e cooptar. Entretanto, o futuro conde de Assumar ressentiu-se de sua mera posição como governador de capitania, num momento de mutação silenciosa das práticas políticas. D. Pedro Miguel careceu de alçada para castigar rapidamente os rebeldes da sublevação, interpretada por ele como afronta ao poder régio e a si mesmo. Recorreu, então, aos vultos do passado para ajudá-lo, à maneira de Maquiavel.

No Discurso histórico..., as ideias d'O príncipe estão presentes, por exemplo, pela dissimulação verificada nas ações do governador para reprimir a revolta. Esse tipo de ardil não era exclusivo aos conselhos do secretário florentino. Contudo, a dissimulação seria doravante confundida com a pecha do maquiavelismo, sobretudo nos ambientes católicos que costumavam atacar Maquiavel. Também o predomínio de autores clássicos, verificado nas duas fontes ora comparadas, foi disseminado em toda a época moderna. Por sua vez, o determinismo geográfico para explicar a periculosidade dos habitantes

${ }^{79}$ Laura de Mello e Souza (org.), Discurso histórico e politico sobre a sublevação que nas Minas houve no ano de 1720, Belo Horizonte, Fundação João Pinheiro, 1994, p. 138.

80/dem, Ibidem, p. 148. Ver Michel Senellart, Machiavélisme et raison d'Etat. XIle-XVIIIe siècle, Paris, PUF, 1989 e As artes de governar: do "regimen" medieval ao conceito de governo, Tradução de Paulo Neves, São Paulo, Editora 34, 2006 [1995], p. 47-63; 225-259. 
das Minas seria mais facilmente relacionado aos escritos de Botero do que a Maquiavel.${ }^{81}$ Como vimos, o documento conjugava significados e leituras plurais, mas sempre em prol da hostilização dos sublevados e da legitimidade da repressão. Por isso mesmo, nele um aspecto merece ser evidenciado: o apreço à violência e ao temor. Trata-se de algo bastante característico de vários escritos de D. Pedro Miguel e bem próprio ao pequeno livro sobre os principados, mesmo que o tema fosse revestido, no caso do Discurso histórico..., de comentários e dicotomias pertinentes à moral cristã.

Não há como atestar se o futuro conde de Assumar leu e/ou inspirou-se no pequeno livro que incentivava o castigo intempestivo, as cenas de efeito e o medo dos súditos em relação aos governantes. Como já foi sublinhado, Maquiavel era figura proibidíssima no Antigo Regime português e jamais estaria formalmente presente na biblioteca do depois marquês de Alorna, ou elogiado em qualquer carta ou tratado escrito. Contudo, se neste artigo inferimos sobre as constantes ressignificações e apropriações de leituras, autores e obras no documento tão erudito e inteligente, construído a favor da violência antecipada, é plausível também supor o uso "maquiavélico" e instrumental da tradição clássica veiculada no Discurso histórico... como forma de dissimular, justamente, o escrito do próprio secretário florentino. Pois, afinal, sob as insignes vestes consulares de Cícero, ou por meio da pena de historiadores romanos ilibados no século XVIII português, como Tácito e Salústio, veiculavam-se ideias muito semelhantes às do príncipe maquiaveliano, em busca de poder, glória e fama. Ideias que, quando explicitamente associadas a Maquiavel, só poderiam figurar em escritos sob a forma de um antimaquiavelismo - este sim, frequentemente alardeado conforme os padrões da Inquisição portuguesa e dos índices de livros proibidos.

Muito mais difícil e complexo é perscrutar a incidência velada das ideias de poder pertinentes aos livros de Maquiavel em âmbitos da época moderna que não lhe mencionam, a não ser em perspectiva de oposição. Ou mesmo considerar a sua leitura estereotipada, sob a forma de um maquiavelismo não assumido, num contexto que lhe foi, em princípio, adverso, ao manifestar-se mais afeito à lógica dos pactos políticos de inspiração neoescolástica e católica. Todavia, por esses dois estudos de caso, vimos que, nos séculos XVII e XVIII, as práticas e ideias políticas de certos governadores na América portuguesa não eram tão distantes assim do debate sobre o poder dos príncipes imortalizado por meio do afamado autor - pelo exacerbado pragmatismo político das ações do conde de Óbidos, ou pela defesa do castigo violento aplicado por D. Pedro de Almeida Portugal. Com as ressalvas e ponderações aqui realizadas, é necessário ter cautela e afastar a hipótese do uso direto dos escritos do autor florentino, como se eles fossem um vade-mecum para as ações dos governantes. Entretanto, se não é possível provar de forma cabal nesses casos a influência direta de Maquiavel, neles pode-se identificar ideias e práticas de poder

81Rodrigo Bentes Monteiro, O rei no espelho. A monarquia portuguesa e a colonização da América 1640-1720, São Paulo, Hucitec, 2002, p. 179-187; 293-307. 
bastante análogas às reflexionadas pelo autor florentino. Em suma, é possível constatar a existência de "maquiavelismos", conforme o próprio antimaquiavelismo concebia o termo "maquiavelismo", embora ele fosse formalmente tão combatido naquele mundo lusitano. Como lembrou o ilustrado português Luís Antônio Verney no século XVIII, Maquiavel falava somente "aquilo que se pratica todos os dias nas cortes e outras partes". ${ }^{82}$ Por essa simples e clara visão, príncipes da Europa e governantes ultramarinos depararam-se com problemas semelhantes em seus governos. A propósito, essa comparação entre âmbitos tão distantes no espaço e no tempo fazia-se presente nos escritos do próprio Maquiavel. Portanto, ao seu modo, o autor florentino foi um compilador de situações pretéritas e de seu próprio tempo, buscando nelas as lições para melhor aconselhar aos governantes. 


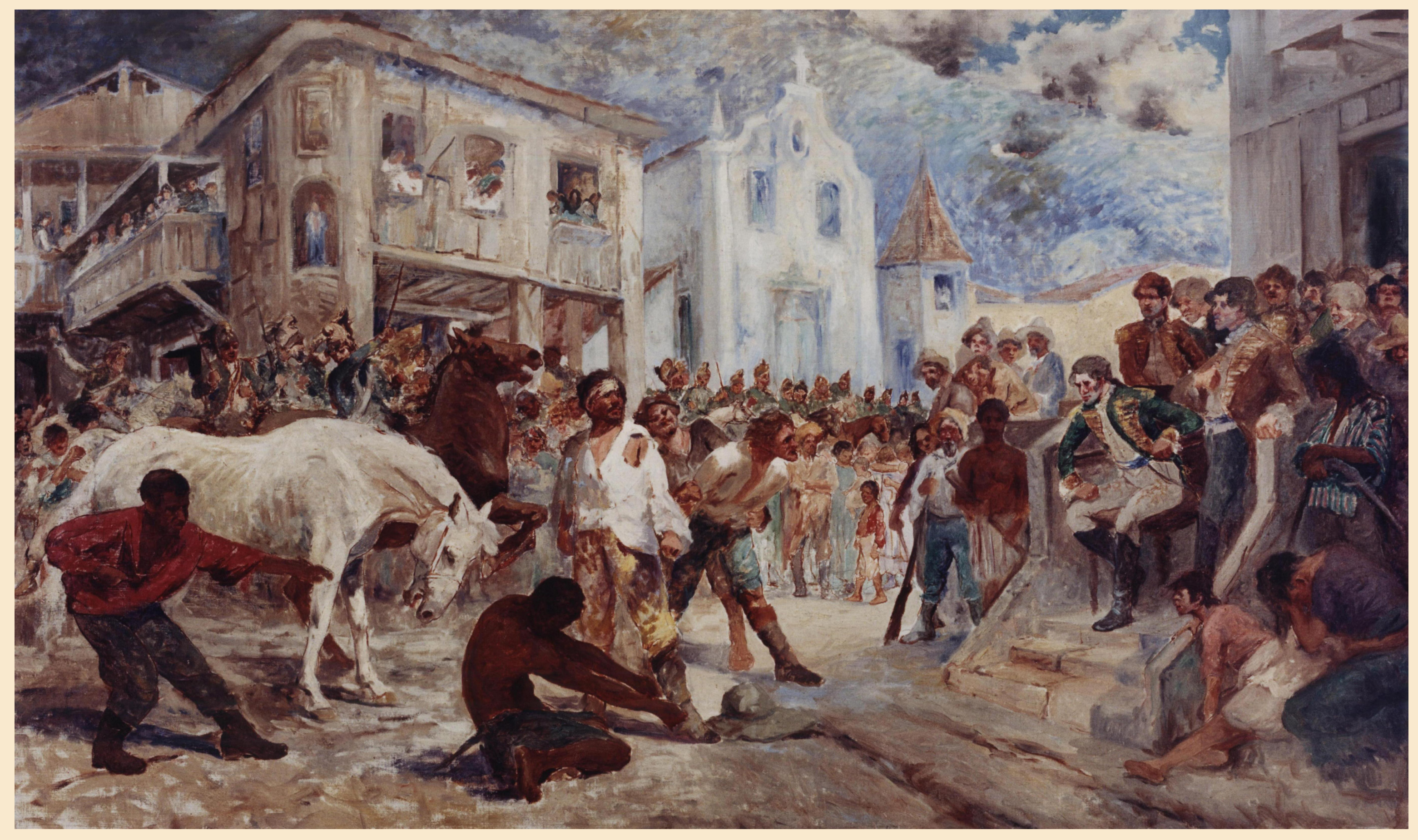

Estudo do pintor Antonio Parreiras (1860-1937) para o quadro Julgamento de Felipe dos Santos, pintado em 1923 sob encomenda do governo de Minas Gerais. O quadro foi destruído em 1959 no incêndio na Assembleia Legislativa em Belo Horizonte. A imagem insere-se no âmbito de heroicização do rebelde de 1720 durante a república brasileira. À direita, sentado vê-se a figura de D. Pedro Miguel de Almeida Portugal, cuias ideias políticas respaldaram seu governo na capitania de São Paulo e Minas do Ouro e a redação do Discurso histórico... Ao fundo, a fumaça do incêndio no morro do Ouro Podre. Dimensão: A 88,4 x L 148,2 cm - A 104,4 x L 164,5 x E 6,3 cm (com moldura). Governo do Estado do Rio de Janeiro/Secretaria de Estado de Cultura/Fundação Anita Mantuano de Artes do Estado do Rio de Janeiro - Funarj/Museu Antonio Parreiras, Niterói (RJ). 